\title{
The First Competitive Examinations for Teacher Selection: The Construction of Order without Didactics
}

\author{
Eurize Caldas Pessanha \\ Graduate Program in Education, Center for Humanities and Social Sciences (Centro de Ciências Humanas e \\ Sociais-CCHS), Federal University of Mato Grosso do Sul (Universidade Federal de Mato Grosso do \\ Sul-UFMS), Campo Grande, Brazil \\ Email: eurizep@hotmail.com
}

Received 22 February 2014; revised 18 March 2014; accepted 8 April 2014

Copyright (C) 2014 by author and Scientific Research Publishing Inc. This work is licensed under the Creative Commons Attribution International License (CC BY). http://creativecommons.org/licenses/by/4.0/

(c) (i) Open Access

\section{Abstract}

The main purpose of this article is to analyze the competitive examinations (concursos) developed for the hiring of public school teachers in Brazil in the XIX century. An analysis of these competitive examinations explaining the characteristics that the government required of people whom it wished to hire as teachers represents an important approach to recovering the history of teachers, which the history of teacher training programs and Didactics itself seems to hide. The research on which this article is based has the goal of discussing the history of the subject from the standpoint of analyzing the exams for teacher selection, namely the content, skills, and characteristics required of an individual to be hired as a teacher in a public school. Considering that Didactics is the subject from which future professionals acquire everything that they must know and the skills necessary to be a professional, we dig into the history of this school subject related to the history of Normal Schools (teacher training schools) in Brazil. We also present the analysis of the competitive examinations for teacher selection, considering the content, skills, and characteristics required for an individual to be hired as a teacher in a public school. In our attempt to analyze this process, we highlight legislative acts from 1809 to 1880 related to the hiring of teachers in the Primitivo Moacyr collection. These sources contain the respective exams and procedural documents for the following years: 1876, 1878, 1881, 1883, 1884, 1885, and 1886. All evidence appears to indicate that although the competitive examinations, including all official apparatus, were conducted as a matter of appearances only, their legitimacy was still provisional, as suggested by both the procedural documents and some legal documents. We conclude that the knowledge required to hire teachers was not Didactics but behavior because, in countries such as Brazil where the "welfare state" was never completely constructed, the school served as the first "reception room" of the state, and the elementary school teacher, always a woman, was the "receptionist". 


\section{Keywords}

\section{Teachers, Brazil, XIX Century, Exams, Didactics, Order}

\section{Introduction}

Of all sectoral policies, education policy is perhaps the clearest example of how the State seeks to produce an appearance of equal opportunities and, with it, neutrality with respect to classes (Offe, 1990: p. 42).

The main purpose of this article is to analyze the competitive examinations (concursos ${ }^{1}$ ) developed for the hiring of public school teachers in Brazil in the XIX century. An analysis of these competitive examinations that explains the characteristics that the government required of people whom it wished to hire as teachers represents an important approach to recovering the history of teachers that the history of Didactics itself and of teacher training programs seems to hide.

The goal of the research ${ }^{1}$ on which this article is based is to discuss the history of the subject based on an analysis of the exams for teacher selection, namely the content, skills, and characteristics required for someone to be hired as a teacher in a public school.

First, we explain how the "research field" known as the "history of school subjects" has been considered to provide a promising framework for the analysis of the classroom (Santos, 1990, 1995; Saviani, 1994).

Considering that Didactics is the subject from which future professionals acquire everything that they must know and the skills required to be a professional, we dig into the history of this school subject related to the History of Normal Schools (teacher training schools) in Brazil.

Then, we present our analysis of the competitive examinations for teacher selection with respect to the content, skills, and characteristics required for someone to be hired as a teacher in public schools.

\section{History of School Subject: A Promising Framework}

The assumptions that a school is the "locus" of specific knowledge produced within the school and for the school from other types of knowledge, scientific or otherwise and that the study of school subjects is necessary to understand and properly treat the specifics of this supposed "knowledge learned in school" are the basis of a research field that emerged in Brazil in the 1990s as a promising approach to understanding the schooling process. $^{2}$

Chervel (1993) provides some clues concerning the possibilities offered by studying the history of school subjects. For the author, school practices provide information regarding the production of knowledge that is not found at the level of production within the sciences or other constructs of society. For this purpose, he suggests the study of school notebooks, for example, which contain millions of written pages that can reveal a story that has not yet been told or analyzed.

If we consider with Santos that the history of school subjects emerged as a reaction to the sociology of a curriculum that constructed overly broad analyses and, thus, that such analyses did not account for the specifics of school practice, one cannot ignore the limitations that result from such shortcomings of these analyses.

Studying a school subject or even a classroom as a "locus," whose analysis and understanding are fully contained within itself, runs the risk of a performing a limited analysis that does not take into account the existence of a society whose conflicts also involve the school. However, there are promising aspects of this approach so long as one considers that the history of a given school subject's formation can reveal the conflicts and contradictions that the society that produced the subject was suffering at that moment in history.

Starting from the assumption that through analysis of the history of school subjects, one can determine how "knowledge from society" was transformed into "knowledge learned in school" to meet the needs of classes or class fractions, the framework of School Subjects is therefore one of the possible methods of analyzing education

\footnotetext{
${ }^{1}$ This study was funded by the National Council of Technological and Scientific Development (Conselho Nacional de Desenvolvimento Científico e Tecnológico-CNPq) and UFMS, and it is titled: “A Didática nos “concursos” de seleção ao magistério primário: revelação das determinações de classe?” ["Didactics in selection “contests” for primary teaching: revealing class determinations?”].

${ }^{2}$ Some studies have been producing important information in this field, such as the studies from Asche, 1997; Bittencourt, 1993; Sampaio, 1997; Pessanha, Daniel, \& Menegazzo, 2004; Pessanha \& Assis, 2011; Pessanha, Assis, \& Oliveira, 2011.
} 
in schools. In the school, which is identified as a "symbolic field," processes occur that are related to the social division of labor and production (Bernstein, 1969). The ways in which these processes are revealed in school vary from the bureaucratic organization of the school to power relations within the school, certainly also including the school subjects.

The hierarchy of school subjects and the evaluation processes are only a few examples of how the social division of labor and the resulting struggle among classes or class fractions manifest in schools. In fact, no school subject is static, and all have a history whose beginning has a more direct relation with the needs of a particular society at a particular historical moment. However, as this history develops, each subject undergoes transformations that hinder the analysis of its relation with society, giving the impression that only its internal factors, or those related to its science of reference, were responsible for its history.

\section{Didactics and the Requirements for Public School Teachers in Brazil}

The subject under focus in this study is the subject of Didactics, the "exemplar" subject of training programs for teachers. This is the subject from which future professionals acquire everything that is necessary to "know" and "know how" to be a professional. Attempts to define the basic content of this subject from the description of the professional "profile" of a teacher have been the stage for discussions and disagreements that have clearly revealed that a teacher's job bears the characteristics of a "semi-profession"”. Anyone who has always "liked to teach" does not need Didactics to learn how to be a teacher.

Moreover, the analysis of the history of the Didactics discipline ${ }^{4}$ seems to display an additional difficulty compared to other fields of knowledge:

[...] Teaching, unlike other areas of knowledge, was defined from the outset as a set of principles and rules to guide a practice, that is, it began where other areas end: it was not formed by a progressive conquest of autonomy through research and reflection that would lead to identifying and delineating its specificity (Soares, 1985: p. 40).

For some, this origin is an obstacle to be overcome so that Didactics may achieve the "status" of other, more respected subjects. However, instead of being treated as an additional difficulty, perhaps this should be considered as the starting point for analyzing the history of the subject of Didactics: a set of prescriptions and rules to guarantee control of education by teachers.

It is interesting to note that Comenius, who is considered in Brazil to be the father of Didactics, in his Didactica Magna, is not concerned with the training of teachers, explaining that

[...] Even masters who have no natural aptitude for teaching will be able to use it with advantage; since they will not have to select their own subject-matter and work out their own method, but will only have to take knowledge that has already been suitably arranged and for the teaching of which suitable appliances have been provided, and to pour it into their pupils. An organist can read any piece of music from his notes, though he might not be able to compose it or to sing or play it from memory; and a school-master, in the same way, should be able to teach anything, if he have before his eyes the subject matter and the method by which it should be taught (Comenius, 1985: p. 457).

As an instrument (of order and control), a teacher must know his purpose, method, and means. To ensure that this is so, the teacher should be selected from among select, pious, honest, decent, and hard-working people. Therefore, there should be less concern with the training of teachers than with their selection, and indeed, the history of training teachers in Brazil seems to follow in accordance with this philosophy.

The history of Teacher Training School in Brazil described by Tanuri and Monarcha records that concern with training teachers has existed since the beginning of the 19th century, but it also relates that there have been disagreements about what exactly qualifies as "solid preparation." For some, this would be "rational learning" or "scientific education;" for others, "a positivist education grounded on a structured didactics from the perspec-

\footnotetext{
${ }^{3}$ Puentes, Aquino and Quillici Neto (2009) concluded that even nowadays there are many approaches about the knowledge, wisdom and necessary abilities to the exercise of teaching.

${ }^{4}$ Chervel states that the word “discipline,” in the sense of "a school subject," as we know it today, is a recent creation. In France, for example, its use is only recorded after World War I, but it maintains the idea of its origin: discipline, order, control. Such a school discipline is the result of the passage of knowledge from society through a specific "filter," to the point that after some time, it no longer has any relation with the original knowledge. For the author, discipline is the price that society pays to pass culture from one generation to another (Chervel, 1993). In French, the word discipline can be used to mean both the action of discipline and a particular school subject. In this text, we will use the term in the sense of a school subject, although that polysemy could be useful for analyzing the role of the Didactic “discipline” in both senses: for teaching content and for disciplining behavior.
} 
tive of historical synthesis” (Monarcha, 1994: p. 203).

An analysis of the creation of Teacher Training Schools in Brazil reveals an utterly erratic history of schools created and not implemented, or implemented and later closed. ${ }^{5}$ The curricula of these first Teacher Training Schools included some general training and "practical" subjects.

Little by little, content regarding "how to teach" was introduced, linked to moral more than technical training, until this content was assembled into a subject whose name began to signify being a good teacher: Didactics.

However, before the implementation of Didactics as a subject, in programs for training teachers in Brazil during the 1930s, which arose with the need to support the expansion of the school network that accompanied the acceleration of urbanization during the same period, the "specific" training of teachers concentrated on "Practical Exercises," the "key to the entire evolution of teaching"6 and a precursor to the current Teaching Practice. The common aspect of all topics covered in these "practical" subjects was their prescriptive character: rules governing teachers' behavior and how to teach. It seems reasonable, therefore, to assume that the Didactics content in these training programs prepared teachers for a more "disciplinarian" than vocational role.

There is no doubt that the history of the subject of Didactics is closely tied to training programs for teachers. However, before the existence of these programs in Brazil, the government had already used exams to select teachers to be hired. The Court, until 1984, used competitive examinations as a criterion to ensure a skilled teaching body for Teacher Training Schools (Tanuri, 1969: p. 22), a practice that continued even after the consolidation of Teacher Training Schools (Tanuri, 1969: p. 8).

Beyond a discussion of the subject itself, it is important to analyze how this history is related to the history of Brazilian society at the time. In this sense, this study does not explicitly adhere to the line of research known as the "history of school subjects," but it uses some of the procedures used by that approach. Beyond the school subject alone, the object of investigation here is Brazilian society.

Concern with conducting examinations to select teachers has been documented since the beginning of the 19th century. The decree of January 17, 1809 "prescribes the manner in which public teachers will be selected in this state of Brazil," mentions the examinations and information required for the provision, and establishes that "some Magistrate able to examine and conduct the procedures of these Masters" should be appointed (Coleção das Leis do Brazil de 1809 [Collection of Laws in Brazil from 1809], Rio de Janeiro, Imprensa Nacional, 1891). Later, Decree 440, from December 10, 1845, regulates the competitive examinations for "public elementary school teaching positions belonging to the County Court, establishing everything from the program to the form of exams and the grading criteria" (Coleção das Leis do Império do Brazil em 1845 [Collection of Laws from the Empire of Brazil in 1845]. In the National Typography, 1845). ${ }^{7}$

All evidence appears to indicate that although the competitive examinations were conducted with all the official apparatus as a matter of appearances only, their legitimacy was still provisional, as suggested by both the procedural documents and some legal documents.

Hiring teachers was a "matter of the State" - to use an expression to the taste of the political "elites" at the time-which should be resolved "politically" and not technically. However, the very existence of the competitive examinations appears to indicate that there was no central power that was sufficiently strong to directly "choose" the teachers that would be hired. Thus, it was necessary to legitimize the choice, thereby resolving and/or avoiding conflicts.

In the attempt to analyze this process, legislative acts from 1809 to 1880 related to the hiring of teachers were highlighted in the collection compiled by Moacyr. Later located in the Historical Archive of Rio de Janeiro, these documents indicate, for example, that since 1809, examinations were given as a means of filling teaching positions

In 1827, the Law of October 15, which Moacyr considers to be the first law concerning teaching in Brazil (Moacyr, 1936a: p. 191), "orders the creation of elementary schools in the most populous cities, villages, and places in the Empire" and also mentions the need for public examinations for teachers:

"Art. 7: Those who wish to be hired for the teaching positions will be publicly examined before the presidents, in Councils; and these will decide who is deemed most worthy and will recommend their nomination to the government" (Collection of Laws in Brazil from 1827-First Part. Page 72).

The conduct of teachers continued to be emphasized: "Art. 8: Only Brazilian citizens who enjoy civil and po-

${ }^{5}$ For further details regarding this history, see Tanuri (1969), Vidal (1966), Silva (1991), and Monarcha (1994).

${ }^{6}$ Decree no. 27 from March 12, 1890 (São Paulo, 1913: pp. 31-32).

${ }^{7}$ The conducting of these "competitive examinations" is recorded through documentation located in the National Archive, where the exams and procedural documents from "competitive examinations" conducted in 1876, and those conducted yearly from 1881 to 1886, are located. 
litical rights, without any remark on the regularity of their conduct, will be admitted to the opposition and examined."

In the case of women, the requirements are more explicit: "Art. 12: [...] women, who are Brazilian with recognized honesty, who showed the most knowledge in the examinations conducted in accordance with Art. 7, will be nominated by the Presidents in Council."

Decree No. 440, from December 10, 1945, "regulates the mode of the competitive examinations for Public Elementary School Teachers belonging to the County Court” based on the Law of October 15, 1827. In fact, it contains very detailed instructions for the examiners and candidates: order of exams, how to perform them, and how to correct them. It should be emphasized that the regulation stipulates that

"Art. 12: If the Minister of the Empire, President of the Competitive Examination, considers, based on what he/she has observed in the Act, and after consultation with the director, that the approval was unfounded and unjust, the Minister will arrange for further examination by other Teachers expressly designated by him/her" (collection of Laws of the Empire of Brazil from 1845, Volume 8, Part 2, Section 37, page 135).

Moacyr transcribes part of the debate that this Law caused, "one of the liveliest of the Chamber" (Moacyr, 1936a: 182). Several speakers emphasized the need for education for Brazilian society, some even detailing how they wanted teachers to teach: I do not want a teacher to teach or point to a straight line, I want the teacher to pick up the compass, describe a triangle on a line; this takes no effort and is the easiest thing possible (page 183). Another expressed doubts regarding giving the responsibility of teaching religious and moral principles to elementary school teachers. Another stated that children needed to learn to be Christian, specifically Roman Catholic, and that the moral component of education is also necessary to learn how to be citizens. From the sample highlighted by Moacyr, it is apparent that lawmakers considered it necessary, and felt they had authority, to descend to the minutiae of a teaching law that was almost a manual for teachers. This appears to indicate that "professional competence," while given as one of the conditions for hiring teachers (Art. 18), may not have truly been an expected attribute, or that this competence had more religious or moral than "professional" characteristics, in the sense that we use today.

On February 17, 1854, the Regulation for the Reform of Elementary and Secondary Education of the County Court was approved, which establishes, in Title II of Public Elementary Education Chapter I C, the requirements for public school teachers and the appointment and dismissal of and benefits for teachers. The Regulation establishes three basic requirements, in addition to being a Brazilian citizen, that a candidate must fulfill to exercise this role:

1) Age of legal majority— “it is proven before the General Inspector by certificate or justification of age” (Art. 13).

2) Morality-when indicating the importance of this requirement, the Regulation is considerably more explicit and detailed, indicating the need for a "police arrest record" and "attestation from respective pastors" and excluding from nomination those people with legal problems or who have committed any other crime that offends public morals or the State Religion (Art. 14 and 15). For women, additional documentation is required regarding marital status, and an age restriction of 25 years is established for single women "unless teaching at their parents' houses and if they possessed recognized morality" (Art. 16). ${ }^{8}$

3) Professional ability - to be proven in the examination, oral and in writing, to be held under the chairmanship of the Inspector General and before two examiners appointed by the government. In addition to establishing the dynamics of the exams, hiring, and remuneration, the Regulation describes, in general terms, the content of the examinations: "The examination will focus not only on the content of their respective subjects of teaching ${ }^{9}$ but also on the practical system and method of teaching itself [...]" (Art. 18). For women, it adds "several arts of needlework" (Art. 19).

In 1881, an electoral law was enacted that required voters to know how to read and write, considerably reducing the constituency. This was a way of facing the redefinition of citizenship-necessary at the time-

\footnotetext{
${ }^{8}$ Teachers' conduct is the subject of a later regulation (Ordinance No. 317 from October 20, 1855), which was prepared for the implementation of Paragraph 8 of Art. 3 of Decree 1331.

${ }^{9}$ The "contents of their respective subjects of teaching" are described in article 47: "Moral and religious education, reading and writing, essential notions of grammar, elementary principles of arithmetic, and the system of weights and measures of the municipality.” They may also include the following topics: "The development of arithmetic and its practical applications; the explicated reading of the Gospels and information from sacred history; the elements of history and geography, mainly of Brazil; the principals of the physical sciences and natural history applicable to uses in life; elementary geometry; land surveying; linear design; notions of music and singing exercises; gymnastics; and a more developed study of the system of weights and measures, not only of the municipality of the Court, but of the provinces of the Empire and the Nations with which Brazil has the most trade relations"(Art. 47).
} 
without incorporating the freed ex-slaves because, out of a population of approximately 14 million people, only 1\% could read and write (Carvalho, 1990: p. 24). ${ }^{10}$ In February of that same year, a competitive examination was conducted for teachers in 7 public teaching positions of Elementary Education in the Municipality of the Court. It can be assumed that the selection of these teachers was related to the need to induct the other $99 \%$ of the population into "citizenship," defined here by the ability to vote.

However, it is known that the political "elites" in Brazil at the time and the bureaucracy that supported the state were highly unrepresentative of the population. One could even say that the educational disparity between the population and the "elites," for whom education was a mark of distinction, was incalculable. While the political "elites" had generally received higher education (almost $80 \%$ of senators), less than $17 \%$ of the free population attended school from 6 to 15 years of age (Carvalho, 1990: p. 25).

Therefore, there was no space for any movement similar to the Progressive Era that propelled the educational reforms in the United States from 1880 to 1920, whose goals ranged from the introduction of civil service in government to the creation of mass schooling for the newly arrived immigrants from Southern and Eastern Europe (Popkewitz, 1997: p. 3).

There was not yet a stable middle class that could, in school, find a means for upward social mobility and for reducing its separation from the "elites," as occurred after the 1930s. Even with the creation of the urban bureaucratic apparatus and services such as banks and trading houses, the number of people who participated in these institutions as lawyers, bureaucrats, and employees was so small that Saes considered them to be "social islands lost in the agrarian universe" (Saes, 1984).

One cannot say that the "elites" did not care about education. Moacyr mentions intense debates in the Legislature during the preparation of the General Education Law of 1827 and other regulations related to public education (Moacyr, 1936a).

More than the legislative debates, which could be predicted to arise when any legislation related to education was being discussed, the so-called production "elites," who were mainly agrarian at the time, proved that they were not strangers to the subject of education. During the Agriculture Congress of 1872, which was conducted in Rio de Janeiro by the initiative of the then-Minister of Agriculture, education was considered by more than one speaker to be a high-priority issue. In fact, among responses to a questionnaire previously sent by the Minister, education appeared as the fourth-highest priority, behind only "capital," "arms," and "railways/communication routes/roads." One respondent even stated, in response to the question "I. What are the most urgent and immediate needs of large-scale farming?," "in order of importance: $1^{\text {st }}$ Public Education, $2^{\text {nd }}$ Public Roads, $3^{\text {rd }}$ Arms, $4^{\text {th }}$ Captains, $5^{\text {th }}$ Repealing the law of 1860 ” (Agriculture Congress, 1988).

While the record that the "elites" cared about education is important, it is also necessary to acknowledge that in the case of the Agriculture Congress, one concern that was strongly emphasized many times ${ }^{11}$ was the need for professional teaching that could avoid the necessity of importing workers. This was one of the proposals that were discussed at the time to resolve predicted problems with the abolition laws, which many of the debaters opposed:

"National workers need to be educated, even compelled: a little energy is needed to attract him/her for agricultural work.

[...] What is needed to grant a new position to farming and the intelligence that drives it [...]

Where are our agricultural schools? (page 133)

It is very surprising that a completely agricultural country such as Brazil has not had, until today, a school where they teach agriculture, because of the government.

[...] One cannot say that it is carelessness or recklessness of the government to retain an agricultural country, until today, without a public school where they teach the basics of agriculture.

[...] Large-scale farming [...] needs municipal schools, at least for the counties. And this is the first necessity, whose satisfaction will make the land used and cultivated by a new system, essential for the transition from the barbarous culture in which we find ourselves to a more civilized and more scientific culture. (page 141)

\section{The Competitive Examination of 1881}

The location of the documentation regarding the competitive examinations began with the "clues" found in

\footnotetext{
${ }^{10}$ Carvalho must be referring here to the entire population, free people and slaves, because according to the 1872 Census, $18.56 \%$ of the free population was literate (Carvalho, 1980: p. 65).

${ }^{11}$ There were 44 mentions of education in 107 pages of speeches.
} 
Moacyr (1936a,b) and was traced through the institutions mentioned by the author. ${ }^{12}$

Documentation containing the respective exams and procedural documents ${ }^{13}$ was located for the "Competitive Examination for Elementary Education-female positions, from 1876," the "Competitive Examination for Associate Professors in Public Schools for Elementary Education, from 1878," and the Competitive Examinations from 1881, 1883, 1884, 1885, and 1886.

The competitive examination considered in this study was conducted during the period of January 18 to March 9, $1881^{14}$, "for providing 7 Public Education teaching positions" in the following elementary schools of the Municipality of the Court: the Single School in the Parish of Nossa Senhora da Conceição da Gavea, the $2^{\text {nd }}$ in the Parish of Jacarepaguá, the $2^{\text {nd }}$ and $3^{\text {rd }}$ in the Parish of Campo Grande, the $2^{\text {nd }}$ and $3^{\text {rd }}$ in the Parish of Ilha do Governador, and the $1^{\text {st }}$ in the Parish of Guaratiba. Twenty-five candidates were enrolled, who underwent written and oral exams, and one of the candidates did not attend the final written exam.

All the exams were conducted on February 18, 1881, and consisted of the following elements: a Text Analysis Exam, which concerned the logical analysis and grammatical analysis of a given text; a Sacred History Exam, which consisted of a dissertation on Joshua that comprised crossing the Jordan, the conquest of Jericho, and the division of the Promised Land; A Religion Exam, which consisted of a dissertation on the Christian Religion; a Pedagogy Exam, which comprised pedagogy, education, and the division thereof; an Arithmetic Exam, which consisted of a dissertation on the addition and subtraction of whole numbers; and a Metrology Exam, which consisted of a dissertation on the units of agrarian measures in the metric system, their multiples and submultiples, and their relations with the conventional system in Brazil.

The judging commission for the competitive examination consisted of three members. This commission corrected the exams, considered that 11 of the 24 candidates who took the exams were qualified, and classified them in order of merit according to the opinion of March 12, 1881. The Board of Directors of the Inspector General of Elementary and Secondary Education, the body responsible for conducting the exams, designated a Commission responsible for reviewing all work from the competitive examination. Because of the number of candidates and, consequently, the number of written exams, this work could not be conducted during a session of the Council. The Commission appointed by the Council considered that the Examining Commission "had excessive benevolence" and did not "find fair the disqualification" of two of the candidates. Thus, it decided to include these two on the list of qualified members and reformulated the rankings. As observed in the correspondence sent by the Inspector of Public Education to the Minister and Secretary of Empire Affairs, this divergence caused conflicts within the Council. One of its members was of the opinion that the Board of Directors did not have the competence to change the decisions of the Examining Commission, which claim was refuted by the President, who, considering himself to be supported by the Regulation, disseminated the list of candidates who were deemed qualified with indications of the schools where they should be hired. In the same correspondence, the Inspector mentions the requirements for five candidates seeking appointment to certain schools. Attached to the list that was sent, there is a list that mentions that some candidates were recommended by the President of the Board and by other doctors or Barons (all those recommended had been considered qualified by the two commissions).

Among the documents that were found, the written exams of 19 of the 25 enrolled applicants were found. ${ }^{15}$ The exams were in good condition, and despite the difficulty of reading a handwritten text that is more than 100 years old, considering the spelling of the time period and careful calligraphy, it was possible to read and analyze the content of each of them. As the goal of this study was to explain the characteristics that the government

\footnotetext{
${ }^{12}$ The tracing of the documentation was conducted in the following institutions in the city of Rio de Janeiro: Center for Documentation (Núcleo de Documentação-NUDOM) of Pedro II College (Colégio Pedro II), located in the City Center; Library of Getúlio Vargas Foundation (Fundação Getúlio Vargas-FGV); National Library (Biblioteca Nacional-BN); and National Archive (Arquivo Nacional—NA). Of these institutions, the latter two were the most useful. The attempt to use the Center for Research and Documentation of Contemporary Brazilian History (Centro de Pesquisa e Documentação de História Contemporânea do Brasil—CPDOC) of Getúlio Vargas Foundation was unsuccessful because it was closed at the time of data collection. At Pedro II College, no information was found concerning "competitive examinations" for elementary school teachers as we initially expected, as the College began offering elementary education only very recently.

13 "Procedural documents" are those produced or presented by the candidates or by the Public Administration bodies, which are distinct from the exams themselves. The "procedural documents" include the minutes of the exams, a list of the candidates who applied to the written and oral exams, and the correspondence between the Inspector General for Elementary and Secondary Education from the Municipality of the Court and the Minister and Secretary of Empire Affairs; they also include documents providing the professional activity, training, and qualifications of a candidate for the examination for a Female Position.

${ }^{14}$ Complete documentation was not found for any of the "competitive examinations.” The most complete documentation was that for the Competitive Examination of 1881, the main source of this study.

${ }^{15}$ Twenty-five enrolled, but only 24 completed all the exams.
} 
required of people who wished to be hired as teachers, the analysis concentrated on content in an attempt to identify differences and similarities between the approved and rejected applicants.

The exams are very similar. All the applicants dissertated on their own subjects, with the exception of the logical-analysis portion of the Text Analysis Exam, in which a common text was provided to all. It was not possible to identify any difference that justified the final ranking. The length of each exam, of which a greater length may be considered to indicate the presence of greater detail in the dissertation, is the only point of difference between the approved exams and the rejected ones, although no pattern was found that indicated a quantifiable correlation. Indications of "excessive benevolence" from the Commission, the Council's justification for the second correction and approval of three candidates rejected by the Commission, were also not found. As a point of curiosity, it was noted that the Text Analysis Exam of the first-place applicant was considerably longer than the others, although one of the rejected applicants used the same number of pages. This first-place exam is nevertheless the exam with the greatest number of notes: underlined words and highlighted paragraphs that appear to have been annotations made by the commissions.

The Pedagogy Exam consisted of a dissertation on the following subject: "Pedagogy, its division. Education." Small variations are evident in the definitions of "education;" however, all define Pedagogy as a science that is divided into physical, intellectual, and moral aspects.

"Pedagogy is a science that studies the principles, laws, methods [...] And processes related to education. It is divided into two branches: Didactics and Methodology. [...] it is divided into physical, moral, and intellectual education" (Januário dos Santos Sabino- $1^{\text {st }}$ place in both Commissions).

"The art of managing education is called pedagogy. It includes two parts, one theoretical and the other practical. [...] taken to a high degree of perfection, or it can be physical, moral and intellectual" (Adalberto Octaviano Arthur de Siqueira Amazonas-1 ${ }^{\text {st }}$ place in both Commissions).

"Pedagogy is the art of education or giving a good education. An important art that needs many lights and vocation. [...] From here, the three branches of education are born: physical, intellectual and moral, in which religious education is included" (Manoel Pereira Junior-rejected by the Commission and ranked in $2^{\text {nd }}$ place by the Council).

"Education is the act of acquiring knowledge (highlighted in the document). Education is divided into physical, moral and intellectual" (Antero Olympio de Siqueira-rejected by both Commissions).

Moral education is the most detailed, which is always related to religion. Only one of the candidates ranked in $1^{\text {st }}$ place does not mention God or religion:

"The harmonious set of these three educations forms the perfect man in a state of living with God, his fellow men (highlighted in the document) and with himself, becoming docile and submissive to the $1^{\text {st }}$ and useful for the $2^{\text {nd }}$ and $3^{\text {rd, }}$ (Adalberto Octaviano Arthur de Siqueira Amazonas- $1^{\text {st }}$ place in both Commissions).

"[...] moral, in which religious education is included" (Manoel Pereira Junior-rejected by the Commission and ranked in $2^{\text {nd }}$ place by the Council).

"God gave us "being" and made us in his image and likeness and gave us enjoyment of all that exists in the world [...]" (Antero Olympio de Siqueira—rejected by both Commissions).

\section{Construction of Order without Didactic}

The analysis of the process described in the procedural documents of the Competitive Examination of 1871, in which the Commission rejected three applicants later ranked by the Council Commission among the top five applicants, and the indications that accompanied the list of approved people clearly reveal that the exam results of the competitive examinations were not the true criterion for selecting teachers to be hired by the state.

Additionally, the near-homogeneity of the Pedagogy Exams, which suggests the existence of some work used by all, indicates that no specific information was required for the areas of Pedagogy, Didactics, and Psychology. This situation was very different from what would occur during the 1960s, when, to be hired, teachers underwent an examination for which the content listed in note 9 was replaced with General Didactics (with 5 Units), Special Didactics (with 5 Units), and Educational Psychology and Learning (with 12 Units), according to the Program for the Entrance Exams for Elementary Education in the State of Rio de Janeiro, during the 1950s (Gonçalves, Bastos, \& Rodrigues, 1959).

A comparison almost automatically emerges with the history of the profession of elementary school teachers in Brazil, according to Pessanha (1994). In the previous century, elementary school teachers did not have great 
social and political importance, and teachers were hired from among women of a certain social class, in this case, poor women without families, with the perspective that if they did not rise socially, at least they would not "decay" to an "indecent" way of life. In the 1950s, pressured by increased urbanization and the demand of the "middle class," the state significantly increased the number of vacancies in schools and thus was in need of a massive number of teachers. Those teachers were mostly women from the rising "middle class" or the "declining," for whom the profession represented a means of steady employment.

While the difference in content between the exams from the two eras is readily apparent, indicating a process of "scientification" of education that has been analyzed with respect to its relation to the exercise of power, ${ }^{16}$ in the specific case of teachers, there is not a large difference between a teacher applicant who, in 1871, described in one or more pages his ideas on Pedagogy, which were essentially the same as those of his peers and evaluators, and a teacher applicant who responded to objective multiple-choice questions based on exactly the same program (and book) as his colleagues.

The "construction of order" and the "formation of souls," to use the expressions of Carvalho $(1980,1990)$, were priorities for the political "elite" that directed Brazil at the end of the 19th century for the preparation and construction of the ideas of the Republic that was looming.

There is no doubt that elementary school teachers actively participated in the construction of this order. However, the exams also demonstrate that it was not necessary to demand any specific knowledge about how to teach, which is related to the content included in the subject of Didactics and which would be the content of the competitive examinations for teacher selection after the 1940s.

Who was included in the construction of this order? Or, in other words, what could be taught by teachers? Certainly nothing that teachers did not know "from the cradle," which therefore implied that there was no need for training programs, exams concerning how to teach, or Didactics.

Fendler, examining the genealogy of the educated subject, raises the question What is teachable? and analyzes the first formulations of didactics in Plato \{teachability of virtue versus paideia \{natural accrual of virtue . The different approaches of paideia and didactics embed different assumptions about the constitution of the subject. On the one hand, paideia embeds the assumption of a holistic and complete nature; there is no need to intervene in the "natural" growth of the person toward virtue. By the same token, the possibility of becoming educated was determined by birth, and not available to most people. On the other hand, didactics embeds the assumption of an incomplete or imperfect nature that requires the intervention of a teacher to cultivate virtue. Simultaneously, the technology of didactics embeds the assumption that the possibility of being "educated" was not limited by birthright (Fendler, 1998: pp. 41-42).

Hamilton identified the circumstances that, in the 16th century, made the distinction between Pedagogy and Didactics possible: while the first is directed toward parents and is related to training/education in the broad sense (upbringing), the second is directed toward teachers and is more related to instruction. In his studies, he reconstructs the relation between the construction of the state and schooling: the political aspirations of the modern state were to be fostered through a state-sponsored institutional matrix-modern schooling (Hamilton, 1999: p. 16).

At the end of the 19th century, the construction of order adopted the technologies of Didactics and all scientific discourse, which would constitute this field during the 20th century, whose goal was to "govern the soul," in the words of Popkewitz:

What appears in school as "science," "math," "composition," or "art" has little relation to the intellectual field that bears the same name, but rather is a pedagogical construct that conforms to expectations related to the school timetable, conceptions of childhood, and conventions of teaching that transform knowledge and intellectual inquiry into a strategy for governing the "soul" (Popkewitz, 1997: p. 9).

In the case of Brazil, the need for prescriptions and, therefore, the inclusion of the subject of Didactics, and no longer merely Pedagogy, emerged when other class fractions began to have access to schooling. When only people "of noble birth" had access to schooling, there was no need for technical intervention to "educate." However, when school was made available to "others," it became necessary to guarantee that the distinction between the educable and non-educable could be made in a technical manner, through the technical subject of Didactics. This distinction, however, is not as clear as it appears. The two concepts-pedagogy and didacticscoexist in the subjects of Teaching Practice and Didactics, being at the root of an "identity crisis" that the subject

\footnotetext{
${ }^{16}$ Governmentality, a concept developed by Foucault, has been widely used in analyses of the construction of knowledge, particularly within the schooling process (see Popkewitz \& Fendler, 1999).
} 
has been undergoing throughout the past two decades.

The hypothesis that teachers serve as receptionists of the state is raised. ${ }^{17}$ In countries such as Brazil, in which the "welfare state" was never completely constructed (Oliveira, 1998), the school would be the first "reception room" of the state, and the "elementary school teacher," always a woman, would be the "receptionist" who determines who can or cannot have access to the other "rooms."

The knowledge required for a receptionist is not directly related to the activities that the receptionist executes, but rather is her ability to determine how far a recently arrived person may go within a company. For teachers, knowledge would be required that guarantees the ability to screen, not to teach. This knowledge historically varies, mainly in relation to the extent of access to schooling. The greater the initial access, the more "sophisticated" the mechanism for teacher selection would be. In this sense, the Competitive Examination of 1881 was less "sophisticated" than are the corresponding current examinations. However, "order" was already being constructed, even without Didactics.

If, at the end of the XIX century, the construction of order and the salvation of souls demanded nothing from teachers other than their innate knowledge, aside from formation courses, tests on how to teach, and the Didactics school subject, in the 1930s, society assumed the position (at least partly) that was necessary to give a convincing and ordered answer to the renovating movement of the 1920s, during which the direction of development in Brazil presented possibilities that provoked fear in the elites (Pessanha, 2000).

This is only a working hypothesis, which deserves greater in-depth study; it will be further tested in the extension of this study to competitive examinations conducted in more recent time periods.

\section{References}

Agricultural Congress (1988). Congresso Agrícola do Rio de Janeiro: Collecção de documentos [Agricultural Congress of Rio de Janeiro: Collection of Documents]. Rio de Janeiro: Fundação Casa de Rui Barbosa, Ed fac-similar.

Asche, E. (1997). Curto-circuito do saber: O ensino de Língua Portuguesa na rede pública estadual paulista na década de 70 [Short Circuit of Knowledge: The Teaching of Portuguese Language in the São Paulo State Public Network in the 1970s]. Ph.D. Thesis, São Paulo: PUC/SP.

Bernstein, B. (1996). A estruturação do discurso pedagógico: Classe, códigos e controle [The structuring of pedagogic discourse: class, codes and control]. Petrópolis: Vozes.

Bittencourt, C. M. F. (1993). Livro didático e conhecimento histórico: Uma história de saber escolar [Textbook and Historical Knowledge: A History of School Knowledge]. Ph.D. Thesis, São Paulo: FFLCH/USP.

Carvalho, J. M. (1980). A construção da ordem: A elite política imperial [The Construction of Order: The Imperial Political Elite]. Rio de Janeiro: Campus.

Carvalho, J. M. (1990). A formação das almas: O imaginário da república no Brasil [The Molding of Souls: The Imagery of the Republic in Brazil]. São Paulo: Companhia das Letras.

Chervel, A. (1993). Histoire de l'agrégation: Contribuition à l'histoire de la culture scolaire [History of Aggregation: Contribution to the History of the School Culture]. Paris: INRP/Éditions Kimé.

Collins, R. (1989). Femmes, stratification sociale et production de la culture [Women, Social Stratification and Production of Culture]. Sociologie et Societés. Paris (XXI), 2, 27-45.

Comenius, J. (1985). A didática magna [Didactica Magna]. Lisboa: Fundação Calouste Gulbenkian.

Fendler, L. (1998). What Is It Impossible to Think? A Genealogy of the Educated Subject. In T. S. Popkewitz, \& M. Brennan (Eds.), Foucault's Challenge: Discourse, Knowledge, and Power in Education. New York: Teachers College Press.

Gonçalves, R., Bastos, A. V., \& Rodrigues, L. S. (1959). Compêndio de pedagogia. (de acordo com os programas do Concurso de Ingresso ao Magistério e das Escolas Normais) [Compendium of Pedagogy. (According to the Programs of the Competitive Examination for Teacher Positions and of the Teacher-Training Schools]. Rio de Janeiro: Freitas Bastos.

Hamilton, D. (2001). Notes from Nowhere: On the Beginnings of Modern Schooling. In T. S. Popkewitz, B. M. Franklin, \& M. A. Pereyra (Eds.), Cultural History and Education: Critical Essays on Knowledge and Schooling (pp. 187-206). New York: Routledge Falmer.

Julia, D. (2001). A cultura escolar como objeto histórico [The School Culture as an Historical Object]. Revista Brasileira de História da Educação, Campinas, 1, 9-43.

Moacyr, P. (1936a). A instrução e o império (Subsidios para a história da Educação no Brasil), 1823 a 1853 [Education and

${ }^{17}$ Collins argues that women tend to occupy posts that are specialized in tasks related to the initial impression of a certain organization or company, in positions such as receptionists and secretaries, thus controlling access to the backstage, benefits, secrets, and directors of the organization (Collins, 1989). 
the Empire (Contributions to the History of Education in Brazil, 1823 to 1853)]. São Paulo: Companhia Editora Nacional.

Moacyr, P. (1936b). A instrução e o império (Subsidios para a história da Educação no Brasil), 1854 a 1889 [Education and the Empire (Contributions to the History of Education in Brazil, 1854 to 1889)]. São Paulo: Companhia Editora Nacional.

Monarcha, C. (1994). Escola Normal da praça: O lado noturno das luzes [Teacher-Training School of Praça da República: The Dark Side of Lights]. Ph.D. Thesis, São Paulo: PUC.

Offe, C. (1990). Sistema educacional, sistema ocupacional e política da educação: Contribuição à determinação das funções sociais do sistema educacional [Education System, Occupational System and Education Policies: Contribution to the Determination of the Social Functions of the Education System]. Educação e Sociedade, 13, 9-59.

Oliveira, F. (1998). Os direitos do antivalor. A economia política da hegemonia imperfeita [The Rights of the Anti-Value: The Economic Policy of the Imperfect Hegemony]. Petrópolis: Editora Vozes.

Pessanha, E. C. (1994). Ascensão e queda do professor [The Rise and Fall of the Teacher]. São Paulo: Cortez.

Pessanha, E. C. (2000). Os primeiros concursos de seleção de professores: A construção da ordem sem Didática [The First Competitive Examinations for the Selection of Teachers: A Construction of the Order without Didactics]. In A. C. do N. Osório (Org.), Registros de Educação [Records of Education] (pp. 103-124). Campo Grande: Editora da UFMS.

Pessanha, E. C., \& De Oliveira, S. S. (2011). A cultura humanista e a cultura científica na história de disciplinas escolares de uma escola secundária (1939-1971) [The Humanistic Culture and the Scientific Culture in the History of School Subjects in a Secondary School (1939-1971)]. Cadernos de Pesquisa em Educação PPGE-UFES, 17, 102-121.

Pessanha, E. C., Daniel, M. E. B., \& Menegazzo, M. A. (2004). Da história das disciplinas escolares à história da cultura escolar: Uma trajetória de pesquisa [From the History of School Subjects to the History of School Culture: A Research Path]. Revista Brasileira de Educação, 57-69.

http://www.scielo.br/scielo.php?script=sci_arttext\&pid=S1413-24782004000300005\&lng=en\&tlng=pt

Pessanha, E. C., Oliveira, S., \& Assis, W. (2011). Muito além de papéis velhos: Fontes para história de disciplinas escolares armazenadas em um arquivo escolar [Far beyond Old Papers: Sources of the History of School Subjects Stored in a School Archive]. Revista Educação em Questão (UFRN. Impresso), 41, 164-191.

Popkewitz, T. S. (1997). The Formation of School Subjects. The Struggle for Creating American Institution. Philadelphia, PA: The Falmer Press.

Popkewitz, T. S., \& Fendler, L. (1999). Critical Theories in Education: Changing Terrains and Politics. New York: Routledge.

Puentes, R. V., Aquino, O. F., \& Quillici Neto, A. (2009). Profissionalização dos professores: Conhecimentos, saberes e competências necessários à docência [Professionalization of Professors: Knowledge, Wisdom and Necessary Abilities to Teaching]. Educar em Revista, 169-184.

http://www.scielo.br/scielo.php?script=sci_arttext\&pid=S0104-40602009000200010\&lng=en\&tlng=pt http://dx.doi.org/10.1590/S0104-40602009000200010

Saes, D. (1984). Classe média e sistema político no Brasil [Middle Class and Political System in Brazil]. São Paulo: T.A. Queiroz.

Sampaio. M. M. F. (1997). Um gosto amargo de escola: Relações entre currículo, ensino e fracasso escolar [A Bitter Taste of School: Relationships between Curriculum, Education and School Failure]. Ph.D. Thesis, São Paulo: PUC/SP.

Santos, L. L. (1990). História das disciplinas escolares: Perspectivas de análise [History of School Subjects: Analytical Perspectives]. Teoria e Educação [Theory and Education], 2, 21-29.

Santos, L. L. (1995). História das disciplinas escolares: Outras perspectivas de análise [History of School Subjects: Other Analytical Perspectives]. Educação e Realidade [Education and Reality], 20, 60-68.

Saviani, N. (1994). Saber escolar, currículo e didática: Problemas da unidade conteúdos/método, no processo pedagógico [School Knowledge, Curriculum and Didactics: Problems Related to the Content/Method Unity in the Pedagogic Process]. Campinas: Autores Associados.

Silva, R. N. (1991). Formação de Professores no Brasil: Um estudo analítico e bibliográfico [Training of Teachers in Brazil: An Analytical and Bibliographic Study]. São Paulo: Fundação Carlos Chagas.

Soares, M. B. (1985). Didática: Uma disciplina em busca de sua identidade [Didactics: A Discipline in Search of an Identity]. ANDE-Revista da Associação Nacional de Educação, 5, 39-42.

Tanuri, L. (1969). Contribuição para o estudo da Escola Normal Brasileira [Contribution to the Study of Brazilian TeacherTraining Schools]. Ph.D. Thesis, São Paulo: FFCL-USP.

Vidal, D. G. (1966). Arte prática ou ciência aplicada: O discurso pedagógico e a formação docente [Practical Art of Applied Science: The Pedagogic Discourse and the Training of Teachers]. In S. Gvirtz (Comp.), Escuela nueva en Argentina y Brasil: Visiones comparadas [New School in Argentina and Brazil: Comparative Views] (pp. 89-124). Buenos Aires: Mino y Dávila Editores. 
Scientific Research Publishing (SCIRP) is one of the largest Open Access journal publishers. It is currently publishing more than 200 open access, online, peer-reviewed journals covering a wide range of academic disciplines. SCIRP serves the worldwide academic communities and contributes to the progress and application of science with its publication.

Other selected journals from SCIRP are listed as below. Submit your manuscript to us via either submit@scirp.org or Online Submission Portal.
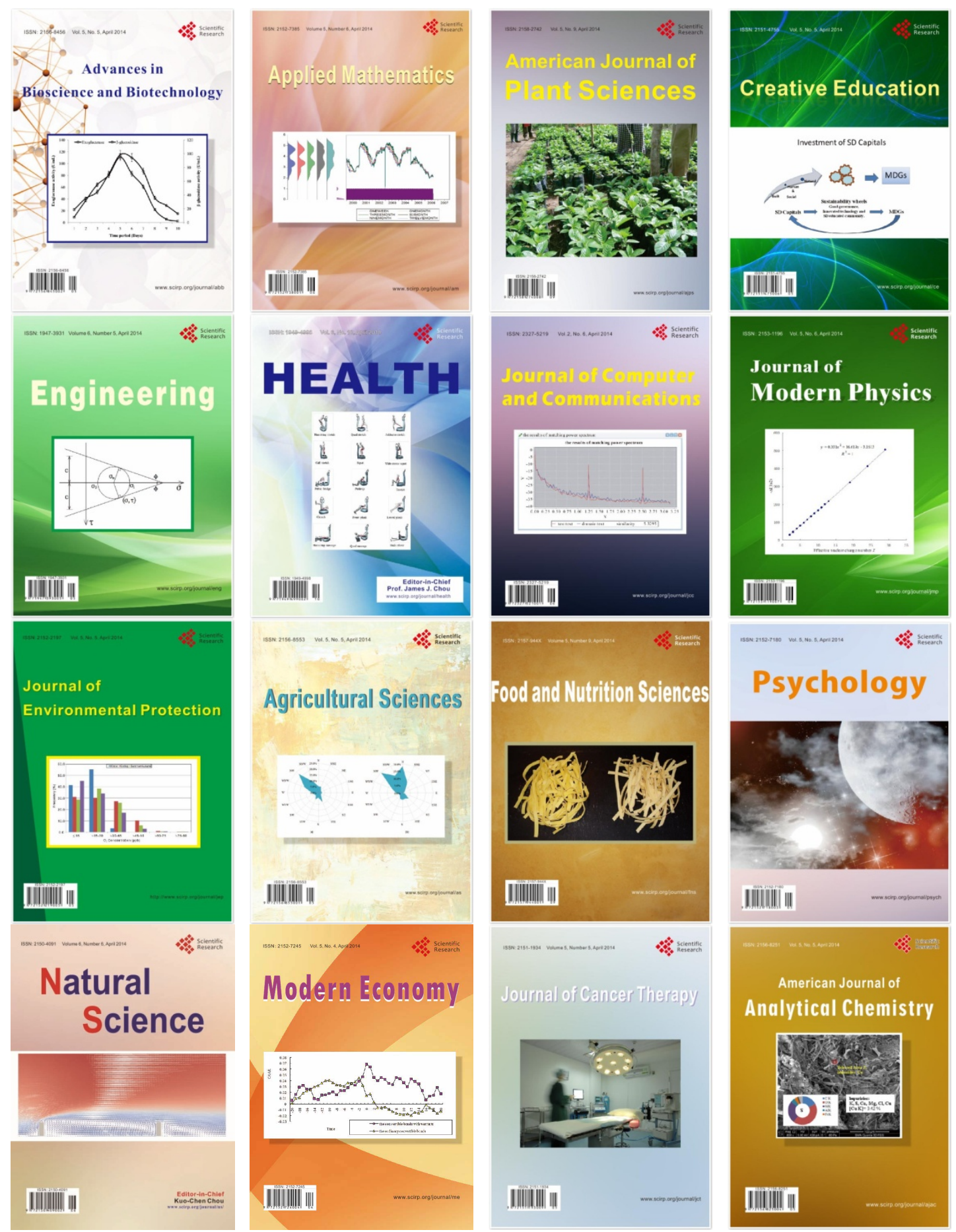